\title{
MRS. A. C. ADAMA VAN SCHELTEMA-KLEEFSTRA
}

On the 31st of December 1953 Mrs. A. C. Adama van Scheltema-Kleefstra, having attained the pensionable age, left the International Institute of Social History, where she had fulfilled the post of librarian. A year earlier Prof. Dr. $\mathrm{N}$. W. Posthumus had resigned from the management and thus the ties of daily work and association between the Institute and the second figure who played a leading part in its foundation and development were broken.

Anna Catharina Kleefstra was born at Lemmer in the province of Friesland on the 25th of February 1884. Her father, J. J. Kleefstra, was a pedagogue who was to follow new directions and rise into note in the field of education. Thus it is quite understandable that his daughter should at first have sought her life task in the same direction. She received her education at Brinio School at Hilversum, founded and led by her father. At first she wished to study mathematics, but she found herself obliged to give up this plan for reasons of ill health. She was trained to be a teacher, and next applied herself to the study of German language and literature.

A career in education, for which she seemed to be destined, was not granted to her. In 1907 she became the secretary of the poet C. S. Adama van Scheltema. She rendered him special assistance in preparing for the press the manuscript of his study $D e$ grondslagen eener nieuzee poëzic (The fundamentals of a new poetry), an endeavour to found poetry, too, on the realization and recognition of human society, in reaction against the individualism that had reigned supreme in Dutch literature since 1880. That same year a marriage resulted from this collaboration; this influenced Mrs Adama van Scheltema's mind in a decisive manner. Already a SocialDemocrat, she now came to move in the highly stimulating world of her husband's friends, young Socialist intellectuals who were soon to take up prominent positions in the scientific and social fields. 
From 1907 to $1913 \mathrm{Mr}$ and Mrs Adama van Scheltema travelled abroad, especially in order to see works of art; amongst other places they stayed for quite a long time in Paris and Italy.

During World War I and the following years Adama van Scheltema and his wife lived in the Netherlands, at Bergen, the home of many artists. During these years they were in close touch with social-political life in the Netherlands, also because of the fact that the poet was one of the editors of the Socialistische Gids (Socialist Guide).

After her husband's death in 1924 the personality of Mrs Adama van Scheltema emerged more sharply defined as the years went by. In the period 1930-1932 she was trained to become a librarian at the University Library at Amsterdam. In the last-mentioned year she took charge of the socio-historical section of the Economic-Historical Library, Amsterdam, led by Prof. Dr N. W. Posthumus; at the same time she was archivist of the Social-Democratic Workers' Party (SDAP). In 1934 she was appointed librarian of the Domela Nieuwenhuis Museum. Her life took an unexpected turn through her urge to collect which was to become even more manifest after her appointment as librarian of the International Institute of Social History.

The Institute was founded in 1935 by Prof. Dr N. W. Posthumus jointly with the Board of Directors of the Centrale Arbeiders-Verzekerings- en Deposito-Bank, and its manager Mr Nehemia de Lieme. In the first place its purpose was to salvage archives and libraries of socio-historical importance from the tidal wave of National-Socialism flooding one Central-European country after another. This opened a wide, if not boundless field for the untiring activity and energy of its first librarian. Without neglecting the Netherlands collections she travelled abroad indefatigably in order to trace, acquire, and bring into the safe refuge of the Amsterdam Institute, collections in danger of destruction, a task which, in view of the political situation in so many countries she could only fulfil with risks to her personal liberty and safety. As the Institute extended its collecting activity to countries 


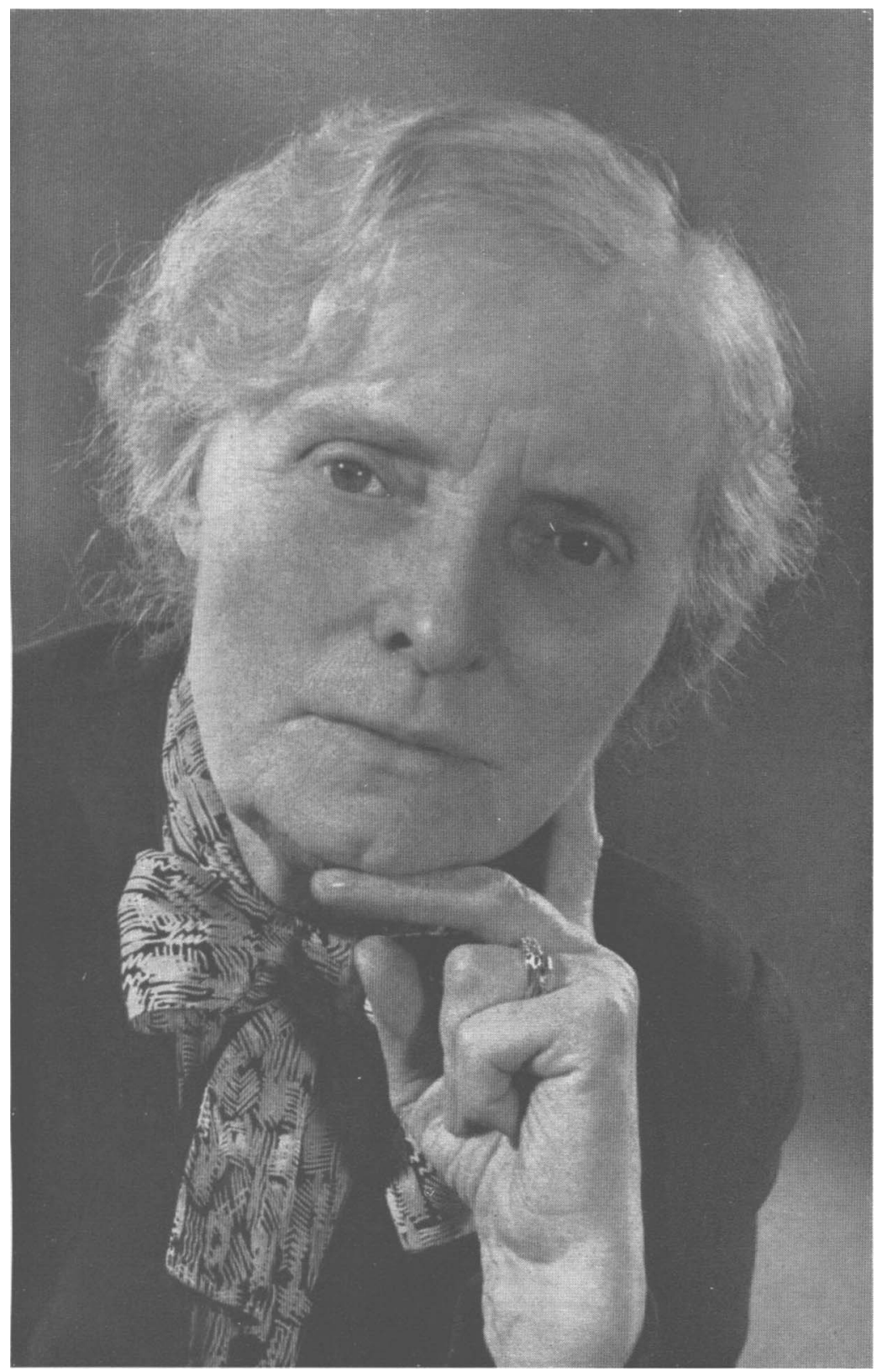

MRS. A. C. ADAMA VAN SCHELTEMA-KLEEFSTRA 
beyond Central Europe, it made increasing demands on its librarian. Moreover, her work remained by no means restricted to the collecting of materials; she took an active part in the arrangement and organization of the Institute, which was growing at an astounding rate, whilst its collections had to be speedily arranged, inventorized, and catalogued.

All these activities came to a painful and sudden end when the German occupier seized the Institute, dismissed its director and the whole staff, and finally carried the entire library - the archives had been removed to safety to England off to Germany. Mrs Scheltema was not at all on good terms with the Germans, but much more heavily than the concern about her personal safety and her livelihood, weighed on her mind the total uprooting of an institution she had helped to build up with such tremendous drive and energy.

This however, did not destroy her energy, but on the contrary, increased it. With great force she devoted herself to the reconstruction of the Institute after the liberation. The ransacked building had to be re-equipped, the archives. brought back from England, the library recovered in Germany, carried back, and, enormous task, re-arranged and catalogued. A new staff had to be formed, and finally, a new financial basis had to be laid. Not only did Mrs Adama van Scheltema take a great part in this task; she also found time and strength to make considerable additions to the collections. Her merits to the Institute were equally great through good and bad fortune, and will not be forgotten.

A. J. C. RÜTER 